\title{
Overcoming class II-linked non-responsiveness to hepatitis $B$ vaccine
}

\author{
Sandra Hervás-Stubbs, Carmen Berasain, José J. Golvano, Juan J. Lasarte, \\ Isidro Prieto, Pablo Sarobe, Jesús Prieto and Francisco Borrás-Cuesta*
}

This work shows that class II-linked humoral lack of response to an antigen can be overcome by joint immunization with the antigen and a T-helper cell determinant $\left(T D_{h}\right)$ well recognized by class II molecules of a non-responder individual. Thus, SJL/J mice $\left(H-2^{s}\right)$, which are non-responders to the $S$ region of hepatitis $B$ virus surface antigen $(H B s A g)$, were rendered responders by joint immunization with a recombinant surface antigen, only composed of the $S$ region, and a short synthetic $T D_{h}$ peptide well recognized by the $H-2^{s}$ restriction. By contrast, when this peptide is not recognized as $T D_{h}$, as in $B 10 M$ mice $\left(H-2^{f}\right.$ restricted and also non-responders to the $S$ region), no humoral response could be induced against the $S$ region. These results have important implications for therapy and vaccination against hepatitis $B$ virus as well as in enhancing the immunogenicity of other antigens.

Keywords: Hepatitis B surface antigen; T-cell help; hepatitis B vaccine; induction of antibodies; synthetic peptides

It is well established that $\mathrm{T}$-cell help can be provided to a hapten by linking this to an amino acid sequence well recognized by $\mathrm{MHC}$ class II molecules ${ }^{1-6}$. This sequence, referred to as $\mathrm{TD}_{\mathrm{h}}$, can also provide help even when not covalently linked to the hapten ${ }^{7}$. These findings suggested to us that an individual who fails to respond to a protein because of lack of recognition of a $T D_{h}$ within its sequence, might be rendered a responder by immunization with this 'haptenic' protein and $\mathrm{a} \mathrm{TD}_{\mathrm{h}}$ peptide chosen to satisfy the class II restriction of this individual. To test this hypothesis we immunized $\mathrm{SJL} / \mathrm{J}\left(\mathrm{H}-2^{s}\right)$ and $\mathrm{B} 10 \mathrm{M}$ $\left(\mathrm{H}-2^{\mathrm{f}}\right)$ mice, two strains of non-responders to the $\mathrm{S}$ region of hepatitis B surface antigen ${ }^{8,9}$, with a recombinant surface antigen, only composed of the $S$ region, in conjunction with a short synthetic peptide well recognized by class II molecules of $\mathrm{SJL} / \mathrm{J}$ but not by those of B10M. We provide below experimental evidence that this simple immunization strategy allows not only the manipulation of the humoral response against an 'haptenic' protein, but is also a convenient way of studying which $\mathrm{TD}_{\mathrm{h}}$ sequences are useful to potentiate the inducton of antibodies in the context of a given restriction. The results are also discussed in terms of the lack of humoral response of a small percentage of humans following immunization with the hepatitis $B$ vaccine.

Departamento de Medicina Interna, Universidad de Navarra, Facultad de Medicina, 31080 Pamplona, Apartado 273, Spain. "To whom correspondence should be addressed. (Received 14 July 1993; revised 10 February 1994; accepted 18 February 1994)

\section{MATERIALS AND METHODS}

\section{Antigens}

The antigen used is a recombinant product (expressed in yeast cells) from Smith Kline and French, S.A. (Engerix-B) and used for vaccination in humans. It is composed only of the S region (amino acids 175-400) of the HBV surface protein. This antigen will be referred to as HBsAg. The $\mathrm{TD}_{\mathrm{h}}$ peptide FISEAIIHVLHSR (designated FIS) corresponds to amino acids 106-118 from sperm whale myoglobin of proved $\mathrm{TD}_{\mathrm{h}}$ character in Balb/c mice ${ }^{10}$ and known to be recognized by class II molecules in $\mathrm{SJL} / \mathrm{J}$ but not in $\mathrm{B} 10 \mathrm{M}$.

\section{Peptide synthesis}

Peptides were synthesized by the solid-phase method of Merrifield ${ }^{11}$ using the Fmoc alternative ${ }^{12}$. The synthesis of $\mathrm{TD}_{\mathrm{h}}$ peptide FIS was done manually and the ninhydrin test of Kaiser et al. ${ }^{13}$ used to monitor every step. Couplings were repeated if necessary until a negative ninhydrin test was attained. FIS was purified by highperformance liquid chromatography (h.p.l.c.) on a reverse-phase $\mathrm{C} 18$ column. The 47 overlapping 14-mer peptides ( $a d w_{2}$ sequence $)^{14}$ from HBsAg were synthesized using a multiple solid-phase peptide synthesizer ${ }^{15}$. They were used without further purification.

\section{Immunization experiments}

Groups of 4-week-old SJL/J $\left(\mathrm{H}-2^{\mathrm{s}}\right)$ or B10M $\left(\mathrm{H}-2^{\mathrm{f}}\right)$ female mice were immunized by intraperitoneal (i.p.) injection of $200 \mu \mathrm{l}$ of an emulsion obtained by sonication 
of $100 \mu \mathrm{l}$ complete Freund's adjuvant and $100 \mu \mathrm{l}$ saline solution consisting of $1 \mu \mathrm{g}$ HBsAg in $50 \mu \mathrm{l}$ Engerix-B vaccine suspension and $50 \mu \mathrm{l}$ phosphate-buffered saline (PBS), or a mixture of $1 \mu \mathrm{g}$ of this antigen and $60 \mu \mathrm{g}$ of $\mathrm{TD}_{\mathrm{h}}$ peptide (FIS). They were boosted at day 30 and 45 with the same dose of antigen in incomplete Freund's adjuvant. Mice were bled from the retro-orbital plexus on days 30,45 and 60 after the first injection.

\section{Titration of antibodies}

Antibodies were titrated by ELISA. Microtitre wells were coated by overnight incubation at $4 \mathrm{C}$ with $50 \mu \mathrm{l}$ peptide solutions $\left(20 \mu \mathrm{g} \mathrm{ml}^{-1}\right.$ of peptide in $0.1 \mathrm{M}$ sodium carbonate buffer) or with $0.1 \mu \mathrm{g} \mathrm{HBsAg}$ in $50 \mu \mathrm{l} 0.1 \mathrm{~m}$ phosphate buffer, $\mathrm{pH}$ 7.0. Wells were then washed three times with a solution of PBS. To block non-specific antibody binding, the wells were incubated with the above buffer but containing $1 \%$ powdered milk and $0.1 \%$ Tween 20 (PBSMT) for $1 \mathrm{~h}$ at room temperature. After removing the PBSMT, $100 \mu$ of different serum dilutions in PBSMT were added and incubated at $37^{\circ} \mathrm{C}$ for $1 \mathrm{~h}$. Wells were washed three times with PBS and then incubated at $37^{\circ} \mathrm{C}$ for $1 \mathrm{~h}$ with a $1 / 1000$ solution of goat anti-mouse IgG biotinylated whole antibody (Amersham, UK) in PBSMT. After washing three times with PBS, wells were incubated with $1 / 500$ dilution of horseradish peroxidase-streptavidin in PBSMT (Amersham, UK) at $37^{\circ} \mathrm{C}$ for $1 \mathrm{~h}$. After washing three times with PBS, the colour reaction was started by adding $100 \mu$ l of a solution prepared by mixing: $10 \mathrm{ml} 0.6 \%$ acetic acid ( $\mathrm{pH} \mathrm{4.7),7.5 \mu l}$ of $33 \%(\mathrm{w} / \mathrm{v})$ hydrogen peroxide and $100 \mu \mathrm{l}$ of $40 \mathrm{~mm}$ aqueous solution of ABTS $\left(2,2^{\prime}\right.$-azino-bis (3-ethylbenzthiazoline-6-sulfonic acid). After $60 \mathrm{~min}$ the plates were read at $405 \mathrm{~nm}$, in a Titertek Multiskan MKII (Flow Laboratories).

\section{IL-2 production assay}

Groups of three mice were immunized at the base of the tail and footpads with $1 \mu \mathrm{g}$ free $\mathrm{HBs} A \mathrm{~g}$ recombinant vaccine or with $1 \mu \mathrm{g}$ of this antigen and $60 \mu \mathrm{g}$ of FIS in complete Freund's adjuvant $(1: 1)$. Ten days after the primary injection, animals were killed and lymph node cells removed. The lymphocytes were then plated on 96-well plates (Costar) at $5 \times 10^{5}$ cells/well with RPMIsupplemented medium alone (RPMI supplemented with $10 \%$ fetal calf serum, $10 \mathrm{~mm}$ glutamine, penicillin $100 \mathrm{U} \mathrm{ml}^{-1}$, streptomycin $100 \mathrm{mg} \mathrm{ml}^{-1}$ and $5 \times 10^{-5} \mathrm{M}$ 2-mercaptoethanol) or with serial dilutions of $\mathrm{HBsAg}$ or FIS in the same medium to a final volume of $0.2 \mathrm{ml}$. Supernatants $(50 \mu \mathrm{l})$ were removed $24 \mathrm{~h}$ later and assayed for the IL-2 content using the CTL-L bioassay as described $^{16}$. Results are presented as stimulation index, which is the ratio of the mean (three determinations) counts $\min ^{-1}$ incorporated in the presence of antigen to the mean (three determinations) counts $\min ^{-1}$ obtained in the absence of antigen.

\section{RESULTS}

\section{Induction of anti-HBsAg antibodies}

To study the effect of a free $\mathrm{TD}_{\mathrm{h}}$ sequence on the induction of anti-HBsAg antibodies SJL/J and B10M mice were immunized with a mixture of $\mathrm{HBsAg}$ (the recombinant product from Smith Kline and French, S.A.,

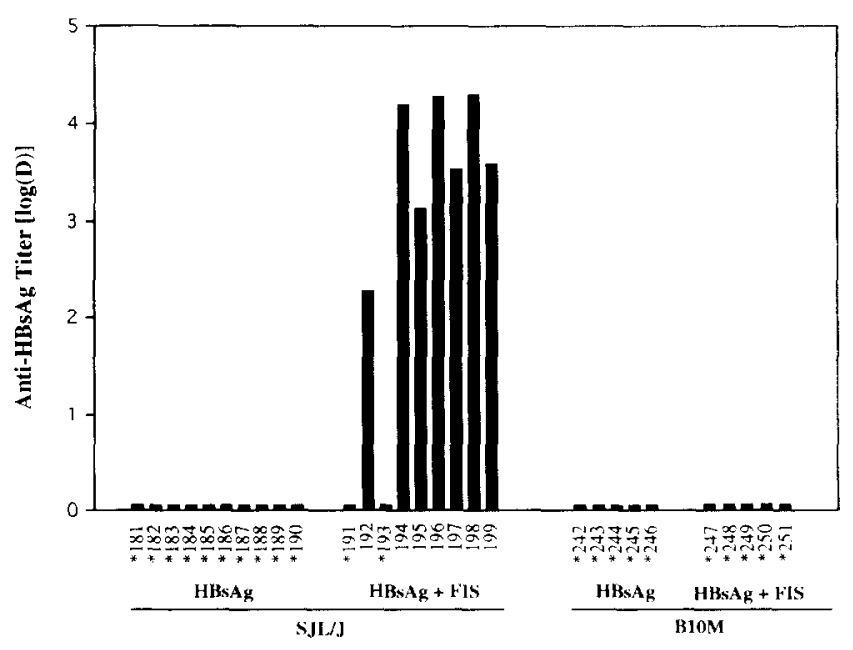

Figure 1 Anti-HBsAg antibodies induced following immunization of $\mathrm{SJL} / \mathrm{J}$ and $\mathrm{B} 10 \mathrm{M}$ mice with either $1 \mu \mathrm{g} \mathrm{HBsAg}$ vaccine in Freund's adjuvant (sera 181 to 190 or sera 242 to 246 respectively) or a mixture of $1 \mu \mathrm{g} \mathrm{HBsAg}$ vaccine and $60 \mu \mathrm{g} \mathrm{FIS} \mathrm{in} \mathrm{Freund's} \mathrm{adjuvant} \mathrm{(sera} 191$ to 199 or sera 247 to 251 respectively). The titres shown are from sera of individual animals at day 60 and correspond to the highest serum dilution to yield three times the absorbance of a negative serum and are expressed as the log of this dilution (D). $\left({ }^{\star}\right)$ No antibodies were detected, a small bar is shown to indicate that the titration has been carried out

used for vaccination in humans) and the $T D_{h}$ peptide FIS, both emulsified in Freund's adjuvant as stated in Methods. We chose these strains because they are reported to be non-responders to $\mathrm{HBsAg}^{8.9}$ and it was known, from IL-2 production assays, that $\mathrm{SJL} / \mathrm{J}$ but not B10M mice were able to recognize FIS as $\mathrm{TD}_{\mathrm{h}}$ peptide.

Figure 1 shows that immunization of $\mathrm{SJL} / \mathrm{J}$ mice with the recombinant $\mathrm{HBsAg}$ vaccine alone was unable to induce anti-HBsAg antibodies in ten out of ten immunized mice. However, immunizations of nine mice with the vaccine mixed with FIS in Freund's adjuvant rendered $\mathrm{HBsAg}$ immunogenic in seven of nine of the immunized mice. By contrast, immunization of B10M mice using the same strategies did not render any of these mice responders to $\mathrm{HBsAg}$.

\section{Mapping the specificity of anti-HBsAg with synthetic peptides}

To map the linear regions of $\mathrm{HBsAg}$, recognized by anti-HBsAg antibodies, we synthesized 47 overlapping 14-mer peptides, encompassing the entire $\mathrm{S}$ region (amino acids $175-400$ of $\mathrm{HBV}$ surface protein) and tested them by ELISA against the antisera diluted $1 / 100$ and $1 / 200$. The recognition was considered positive only if the absorbances of the ELISA assay for serum dilutions 1/100 and $1 / 200$ of immunized animals were at least four times the average absorbance of the corresponding dilution of the serum of a non-immunized animal. The antisera from $\mathrm{SJL} / \mathrm{J}$ mice immunized with $1 \mu \mathrm{g} \mathrm{HBsAg}$ and $60 \mu \mathrm{g}$ FIS were able to recognize several peptides. Most of the tested sera recognized peptides $290-303,295-308$ and the protein (see Table $I$ and Figure 2).

\section{T-cell response to antigens}

To obtain an insight into which $\mathrm{TD}_{\mathrm{h}}$ was responsible for providing $\mathrm{T}$-cell help to anti-HBsAg antibody production cells we immunized $\mathrm{SJL} / \mathrm{J}$ and $\mathrm{B} 10 \mathrm{M}$ mice with recombinant $\mathrm{HBs} \mathrm{Ag}$ vaccine alone and with vaccine 
Short paper: S. Hervás-Stubbs et al.

Table 1 Recognition of 14-mer peptides from the S region of HBsAg and antibody titres induced against HBsAg and FIS

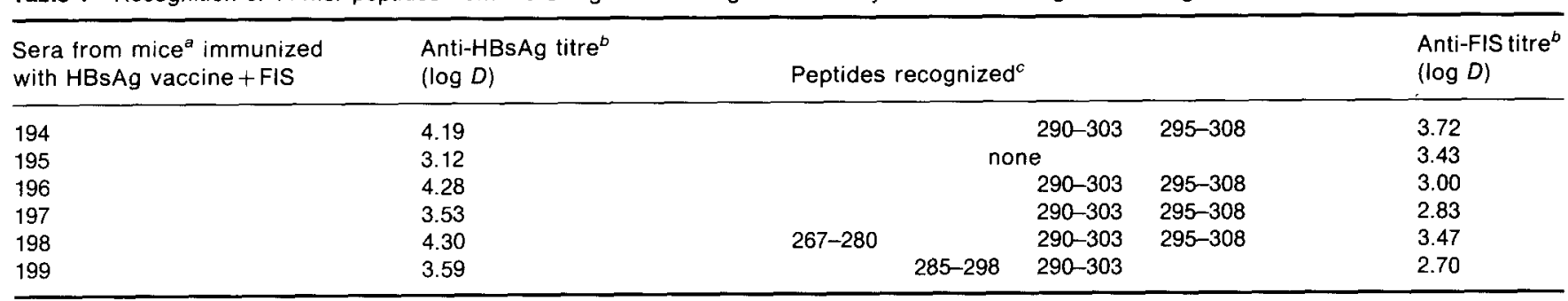

${ }^{a}$ Each number corresponds to the serum at day 60 of an immunized animal. Only sera with an anti-HBsAg antibody titre $>3$ are shown

${ }^{b}$ Titres were determined by the highest serum dilution to yield three times the absorbance of a negative serum and are expressed as the log of this dilution $(D)$

${ }^{c}$ Each peptide is identified by the numbers of the $N$-terminal and $C$-terminal amino acids corresponding to its position within the sequence $1-400$ of the HBV surface protein

together with FIS in identical proportions to the ones used for antibody induction (see Methods). After removal of lymph nodes and plating of the lymphocytes, these were restimulated with FIS and with $\mathrm{HBsAg}$. Figure 3 clearly shows that in the group of $\mathrm{SJL} / \mathrm{J}$ mice immunized with HBsAg vaccine alone, neither FIS nor HBsAg is able to induce IL-2 production, except for a marginal signal at the higher dose of HBsAg. However, FIS but not HBsAg is able to induce IL-2 in the group of SJL/J immunized with the mixture of HBsAg and FIS. By contrast, neither of the two groups of B10M-immunized mice (with $\mathrm{HBsAg}$ alone and $\mathrm{HBsAg}$ in conjunction with FIS) was able to induce IL-2 production.

\section{DISCUSSION}

FIS provides T-cell help to SJL/J mice and renders them responders to immunization with $\mathrm{HBsAg}$

Induction of anti-HBsAg antibodies in $\mathrm{SJL} / \mathrm{J}$ mice was only achieved by immunization with the antigen together with FIS (Figure 1). As has been described before ${ }^{8,9}$ and is shown in Figure 3, the $\mathrm{S}$ region of $\mathrm{HBsAg}$ is unable to induce a $\mathrm{T}$-cell response in $\mathrm{SJL} / \mathrm{J}$ mice. This explains why no humoral response against $\mathrm{HBs} \mathrm{Ag}$ was obtained in the group of mice immunized with the vaccine alone. However, joint immunization with FIS and $\mathrm{HBsAg}$ induces a T-cell response specific for FIS. This, together with the finding that anti-HBsAg antibodies are induced only following joint immunization with veccine and FIS, proves that the $\mathrm{T}$-cell help required to induce the humoral response against $\mathrm{HBsAg}$ must necessarily come from FIS. As suggested previously by this laboratory ${ }^{7}$, we believe that the effect of FIS might be due to direct binding of FIS to class II molecules of a physically close B cell having recognized an epitope (in the present case from HBsAg) via its surface immunoglobulin. Since direct binding would be favoured by an excess of FIS at the immunization site we have used a high ratio of this determinant with respect to $\mathrm{HBs} \mathrm{Ag}$. We cannot provide a clear explanation for the lack of response of two mice from Figure 1 to combined immunization with $\mathrm{HBsAg}$ and FIS. However, it could be tentatively postulated to be due to variability between individuals.

FIS does not provide T-cell help to B10M mice and thus cannot render them responders to immunization with HBsAg

As shown in Figure 1 , immunization of B10M mice with $\mathrm{HBsAg}$ in conjunction with FIS was unable to

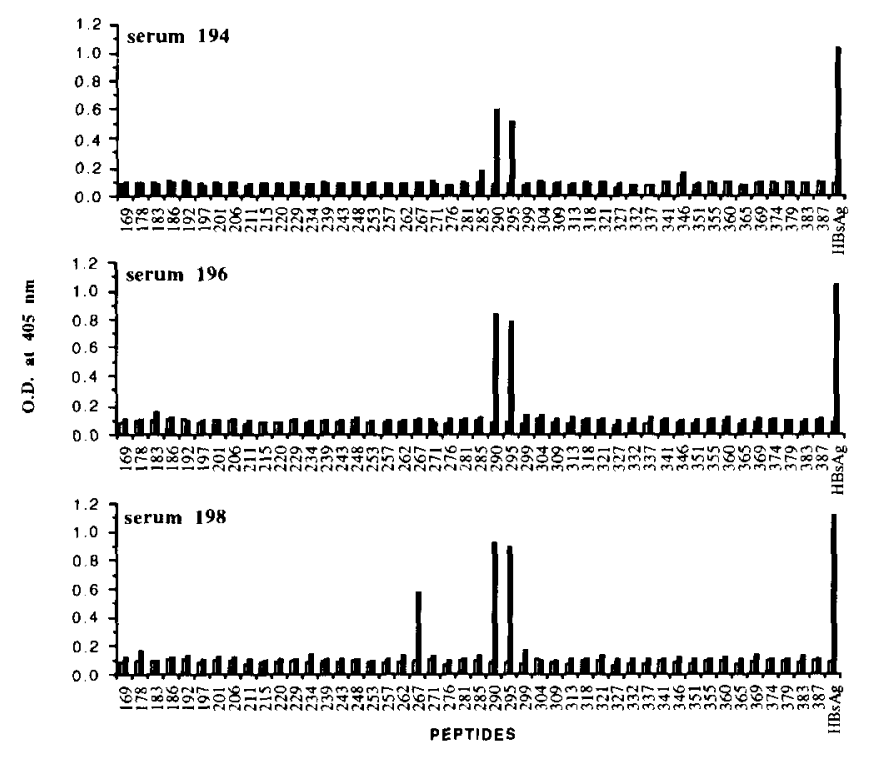

Figure 2 Recognition of 47 overlapping 14-mer peptides (encompassing the entire $S$ region) by anti-HBsAg antibodies induced in SJL/J mice at day 60 , following immunization with a mixture of $\mathrm{FIS}$ and $\mathrm{HBsAg}$ recombinant vaccine in Freund's adjuvant. Only representative sera 194 196 and 198 from Table 1 are shown. For comparison, the recognition of $\mathrm{HBsAg}$ by the antisera is also shown. The absorbance values are those obtained with the serum dilution $1 / 100$. The solid bars relate to the sera of the immunized animals and the open bars to the serum of a non-immunized animal. The peptide numbers correspond to the position of the amino-terminal amino acid of each peptide with respect to the large protein, amino acids $1-400$, of the HBV

render this strain responsive to HBsAg. The experimental explanation of this lack of response is given in Figure 3 . Indeed, the IL-2 production assay shows that, like SJL/J, $\mathrm{B} 10 \mathrm{M}$ mice are unable to recognize any $\mathrm{TD}_{\mathrm{h}}$ sequence within the recombinant vaccine. Moreover, and in contrast to $\mathrm{SJL} / \mathrm{J}$ mice, the strain $\mathrm{B} 10 \mathrm{M}$ is unable to recognize FIS as a TD $_{h}$ peptide. Therefore, since FIS is not recognized as a $T D_{h}$ peptide, no $T$-cell help could be provided and consequently no anti-HBsAg antibodies could be induced. This also corroborates that the role of FIS in SJL/J is to provide specific $T$-cell help for the induction of antibodies.

\section{Mapping the humoral response to HBsAg using synthetic peptides}

As shown in Table 1 and Figure 2, peptides 290-303 and 295-308 were the most commonly recognized among 

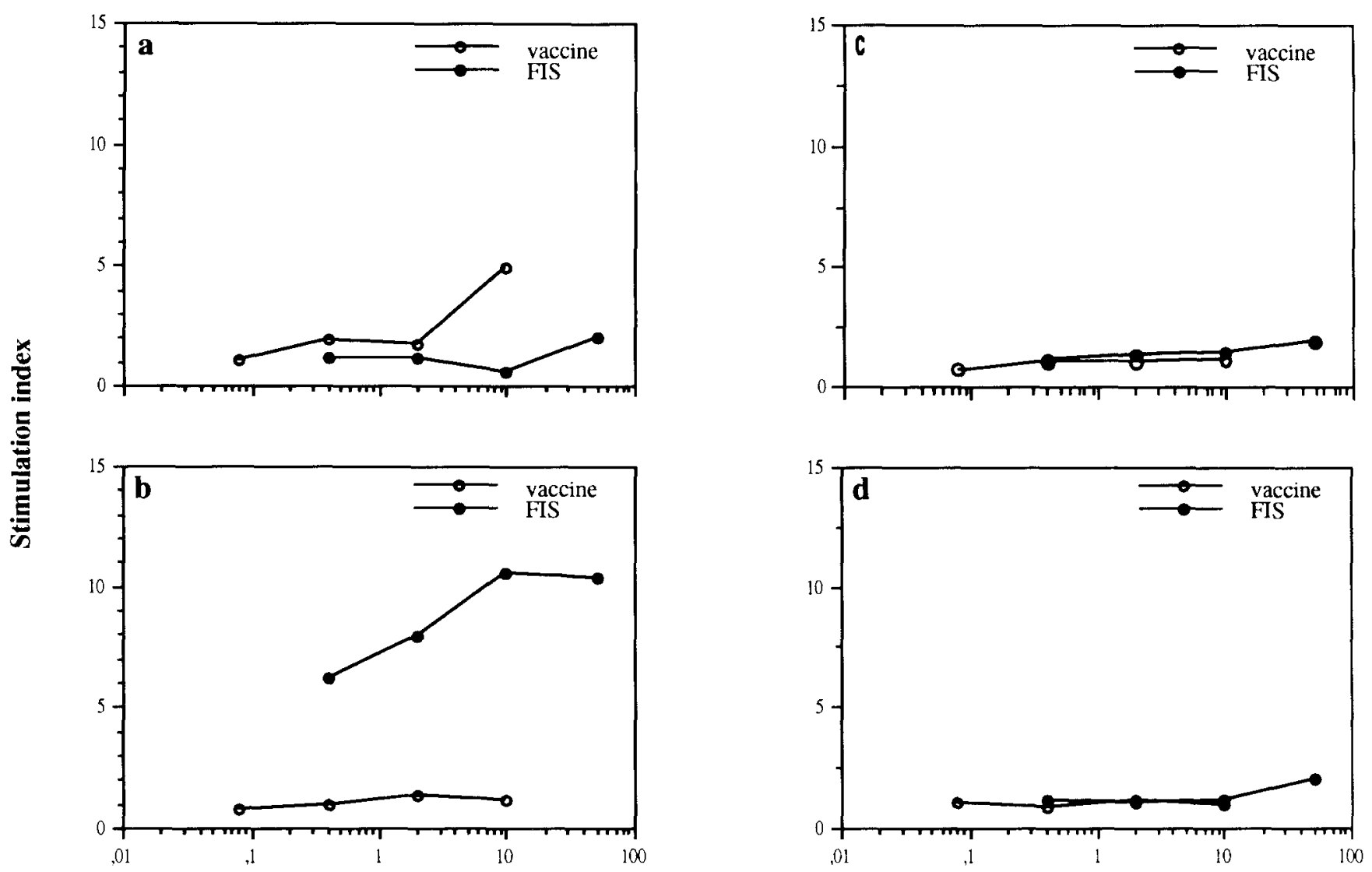

\section{Antigen Concentration $(\mu \mathrm{g} / \mathrm{ml})$}

Figure 3 Identification of the antigen responsible for providing T-cell help. Following immunization of SJL/J and B10M mice with $\mathrm{HBsAg}$ (vaccine) alone $(a, c)$ or with vaccine in conjunction with FIS (b, d), the lymph node cells from these mice were extracted and restimulated in vitro with vaccine or with FIS. As shown in (b) for the group of SJL/J mice immunized with a mixture of HBsAg and FIS, a significant stimulation index is only obtained after in vitro restimulation with FIS

the 47 14-mer peptides from the $\mathrm{S}$ region of HBV surface protein, a result in agreement with the reported evidence $^{17-19}$ that the region $274-331$ contains most of the $B$-cell recognition sites of the $S$ region. Since antiserum 195 was able to recognize HBsAg but not any of the synthetic peptides encompassing this antigen, it would seem likely that the antibodies induced in this mouse may be directed against a conformational epitope of HBsAg not well presented by these short synthetic peptides, although it cannot be excluded that this lack of recognition could be associated with low affinity and/or low antibody titre of immunoglobulins of antiserum 195.

\section{Potential applications of the study}

The strategy of using FIS to potentiate the humoral response has proved to be very successful for other restrictions in our laboratory. Thus, we have induced antibodies in Balb/c mice against more than 100 haptenic peptides (data not shown). Also, in five of five peptides tested, this procedure was also successful in New Zealand white rabbits. We favour this method not only because it bypasses the need to couple the $\mathrm{TD}_{\mathrm{h}}$ peptide to the haptenic molecule, or macromolecule, but also, and perhaps more importantly, because it avoids the risk of inducing unwanted structural changes of relevant epitopes of the antigen due to the coupling of the $T_{\mathrm{h}}$ sequence. There is, however, a potential disadvantage in using the strategy of joint immunization with a $\mathrm{TD}_{h}$ peptide not covalently linked to the hapten, namely the possibility of activating unwanted B lymphocytes specific for other antigens that might be present at the immunization site. Another interesting aspect of the strategy of joint immunization of hapten and $\mathrm{TD}_{h}$ is that it offers the possibility of testing the ability of a $T D_{h}$ peptide to provide suitable $\mathrm{T}$-cell help for antibody production in the context of a given restriction.

With respect to vaccination against $\mathrm{HBV}$, it has been observed that a small proportion of humans are non-responders. This lack of response seems to be due to a lack of T-cell help and is associated with the restriction HLA-A1, B8 and DR $3^{20.21}$. Moreover, this restriction is also associated with chronic active hepatitis ${ }^{22,23}$. Our results of joint immunization with FIS and $\mathrm{HBs} A g$ vaccine obtained in $\mathrm{SJL} / \mathrm{J}$ mice suggest that a similar strategy might be used to induce anti-HBsAg antibodies in those humans who do not respond to vaccination $^{20.21}$ with this antigen. However, if the purpose of this immunization is to confer long-lasting protection against $\mathrm{HBV}$ infection, it might be more adequate to use a suitable $T_{\mathrm{h}}$ peptide from other antigens of the virus to induce memory $T$ cells that could be activated following infection with $\mathrm{HBV}$. 
We believe that immunization with an antigen in conjunction with a suitable $\mathrm{TD}_{\mathrm{h}}$ peptide to overcome non-responsiveness, may make it possible to treat chronically infected patients such as, for instance, those infected by hepatitis B virus (HBV). Thus, if a strong antibody response against the $\mathrm{HBV}$ surface antigen could be induced in these patients (like the one observed in acute hepatitis $B$ following seroconversion) the HBV might be cleared. We are starting experiments to try this hypothesis in an animal model.

\section{ACKNOWLEDGEMENTS}

This work was supported by grants from CICYT (SAL 89-1057) and by Fundación Ramón Areces. S. HervásStubbs acknowledges predoctoral support PN90 31649548 from the Ministerio de Educación y Ciencia, Spain.

\section{REFERENCES}

1 Good, M.F., Malloy, W.L., Lunde, M.N., Margalit, H., Cornette, J.L., Smith, G.L. et al. Construction of synthetic immunogen: use of new T-helper epitope on malaria circumsporozoite protein. Science 1987, 235, 1059-1062

2 Leclerc, C., Przewlocki, G., Chutze, M.P. and Chedid, L. A synthetic vaccine constructed by copolymerization of $B$ and $T$ cell determinants. Eur. J. Immunol. 1987, 17, 269-273

3 Borrás-Cuesta, F., Petit-Camurdan, A. and Fedon, Y. Engineering of immunogenic peptides by co-linear synthesis of determinants recognized by $B$ and T cells. Eur. J. Immunol. 1987, 17, 1213-1215

4 Borrás-Cuesta, F., Fedon, Y. and Petit-Camurdan, A. Enhancement of peptide immunogenicity by linear polymerization. Eur. J. Immunol. 1988, 18, 199-202

5 Cox, J.H., Ivanyi, J., Young, D.B., Lamb, J.R., Syred, A.D. and Francis, M.J. Orientation of epitopes influences the immunogenicity of synthetic peptide dimers. Eur. J. Immunol. 1988, 18, 2015-2019

6 Golvano, J.J., Lasarte, J.J., Sarobe, P., Gullón, A., Prieto, J. and Borrás-Cuesta, F. Polarity of immunogens. Implications for vaccine design. Eur. J. Immunol. 1990, 20, 2363-2366

7 Sarobe, P., Lasarte, J.J., Golvano, J.J., Gullón, A., Civeira, M.P., Prieto, J. and Borrás-Cuesta, F. Induction of antibodies against a peptide hapten does not require covalent linkage between the hapten and a class II presentable peptide. Eur. J. Immunol. 1991. 21, 1555-1558

8 Milich, D.R. and Chisari, F.V. Genetic regulation of the immune response to hepatitis $\mathrm{B}$ surface antigen (HBsAg). I. H-2 restriction of the murine humoral immune response to the $a$ and $d$ determinants of HBsAg. J. Immunol. 1982, 129, 320-325

9 Milich, D.R., McNamara, M.K., McLachlan, A., Thornton, G.B. and
Chisari, F.V. Distinct $\mathrm{H}-2$ linked regulation of T-cell responses to the preS and $S$ regions of the same hepatitis $B$ surface polypeptide allows circumvention of nonresponsiveness to the $S$ region. Proc. Natl Acad. Sci. US A 1985, 82, 8168-8172

10 Cease, K.B., Berkower, I., York-Jolley, J. and Berzofsky, J.A. T cell clones specific for an amphipathic $\alpha$-helical region of sperm whale myoglobin show differing fine specificities for synthetic peptides. J. Exp. Med. 1986, 164, 1779-1784

11 Merrifield, R.B. Solid phase peptide synthesis. I. The synthesis of a tetrapeptide. J. Am. Chem. Soc. 1963, 85, 2149-2154

12 Atherton, E., Logan, J.C. and Sheppard, C.R. Peptide synthesis. Part 2. Procedure for solid-phase peptide synthesis using $\mathrm{N}^{\alpha}$ fluorenylmethoxycarbonylamino-acids on polyamide supports. Synthesis of substance $P$, an acyl carrier protein 65-74 decapeptide. J. Chem. Soc. Perkin Trans. 1981, 1, 538-546

13 Kaiser, E., Colescott, R.L., Bossinger, C.D. and Cook, P.I. Color test for detection of free terminal amino groups in the solid-phase synthesis of peptides. Anal. Biochem. 1970, 34, 595-598

14 Valenzuela, P., Gray, P., Quiroga, M., Zaldivar, J., Goodman, H.M. and Rulter, W.J. Nucleotide sequence of the gene coding for the major protein of HBsAg. Nature 1979, 280, 815-819

15 Borrás-Cuesta, F., Golvano, J.J., Sarobe, P., Lasarte, J.J., Prieto, I., Szabo, A. et al. Insights on the amino acid side-chain interactions of a synthetic T-cell determinant. Biologicals 1991, 19, 187-190

16 Lai, M.Z, Ross, D.T., Guillet, JG., Briner, T.J., Gefter, M and Smith, J.A. T lymphocyte response to bacteriophage $\lambda$ repressor $c$ protein. Recognition of the same peptide presented by la molecules of different haplotypes. J. Immunol. 1987, 139, 3973-3980

17 Peterson, L., Nath, N. and Gavilanes, F. Structure of hepatitis B surface antigen. Correlation of subtype with amino acid sequence and location of the carbohydrate moiety. J. Biol. Chem. 1982, 257 10414-10420

18 Lerner, R.A., Green, N., Alexander, H., Lin, F.-J., Sutcliffe, J.G. and Shinnick, T.M. Chemically synthesized peptides predicted from the nucleotide sequence of the hepatitis $B$ virus genome elicit antibodies reactive with the native envelope protein of Dane particles. Proc Natl Acad. Sci. US A 1981, 78, 3403-3407

19 Bhatnagar, P.K., Papas, E., Blum, H.E., Milich, D.R., Nitecki, D., Karels, M.J. and Vyas, G.N. Immune response to synthetic peptide analogues of Hepatitis $B$ surface antigen specific for the a determinant. Proc. Natl Acad. Sci. US A 1982, 79, 4400-4404

20 Alper, C.A., Kruskall, M.S., Margus-Bagley, D., Craven, D.E. Katz, A.J., Brink, S.J. et al. Genetic prediction of nonresponse to hepatitis B vaccine. N. Engl. J. Med. 1989, 321, 708-712

21 Pol, S., Legendre, C., Mattlinger, B., Berthelot, P. and Kreis, H. Genetic bases of nonresponse to hepatitis $B$ vaccine in hemodyalized patients. J. Hepatol. 1990, 11, 385-387

22 Page, A.R., Sharp, H.L., Greenberg, L.J. and Yunis, E.J. Genetic analysis of patients with chronic active hepatitis. J. Clin. Invest. 1975 , 56, 530-535

23 Opelz, G., Votgen, A.J.M., Summerskill, W.H.J., Schalm, S.M. and Terasaki, P.K. HLA determinants in chronic active liver disease: possible relation of HLA-DR7 to prognosis. Tissue Antigens 1977, 9, $36-40$ 